\title{
Asas Legalitas dalam Hukum Acara Pidana: Kritikan terhadap Putusan MK tentang Praperadilan
}

\author{
Tristam P. Moeliono, Widati Wulandari \\ Fakultas Hukum Universitas Katolik Parahyangan \\ Jl. Ciumbuleuit No. 94 Bandung 40142 \\ Fakultas Hukum Universitas Padjadjaran Bandung \\ Jl. Dipati Ukur No. 35 Bandung 40123 \\ tristam_m@yahoo.com; widati_w@yahoo.com
}

\begin{abstract}
The problem of this research is: how high is the authority of Constitutional Court to amend the provisions of criminal procedure law (KUHAP) by stating that some articles in KUHAP are not constitutional and expanding the authority of judges in pretrial forum. Since 2015, pretrial judges have authority to investigate and decide whether the determination of a suspect is legitimate. The research method was normative juridical. The result shows that Constitutional Court judges have actually replaced the position of lawmakers (legislator) and violated the principles of nullum iudicium sine lege. In relation to that, if the need is to improve the supervision mechanism for the use of coercion in investigations, lawmakers should amend KUHAP or introduce better supervision mechanism for investigators.
\end{abstract}

Keywords: Legal principles, criminal procedure law, pretrial

\begin{abstract}
Abstrak
Pokok permasalahan dalam penelitian ini adalah seberapa jauh kewenangan Mahkamah Konstitusi mengubah ketentuan hukum acara pidana dengan cara menyatakan beberapa pasal dalam KUHAP inkonstitusional dan selanjutnya memperluas kewenangan hakim dalam forum praperadilan. Sejak 2015, hakim praperadilan dinyatakan berwenang memeriksa dan memutus keabsahan penetapan tersangka. Metode penelitian yang digunakan adalah yuridis normatif. Hasil penelitian menyimpulkan, bahwa hakim MK sebenarnya telah menggantikan posisi pembuat undang-undang dan sekaligus melanggar asas nullum iudicium sine lege. Beranjak dari itu, hendak diargumentasikan pula bahwa bilamana kebutuhannya adalah pengembangan mekanisme pengawasan yang lebih baik terhadap penggunaan upaya paksa dalam penyidikan, seharusnya pembuat undang-undang, mengamandemen KUHAP atau mengintrodusir mekanisme pengawasan bagi penyidik yang lebih baik.
\end{abstract}

Kata Kunci: Asas legalitas, hukum acara pidana, praperadilan 


\section{Pendahuluan}

Penelitian ini beranjak dari pertanyaan - rumusan permasalahan hukum seberapa jauh sebenarnya Mahkamah Konstitusi berwenang mengubah ketentuan hukum acara pidana dengan cara menyatakan beberapa pasal dalam KUHAP inkonstitusional dan selanjutnya memperluas kewenangan hakim dalam forum praperadilan. Tujuan yang disasar melalui penelitian ini adalah menguji secara teoretik dan mengkritik salah satu putusan Mahkamah Konstitusi ${ }^{1}$ yang menguji dan menilai KUHAP.

Teramati bahwa dalam salah satu putusan, Mahkamah Konstitusi (MK) ${ }^{2}$ menyatakan KUHAP (Pasal 1 angka 14, Pasal 17, dan Pasal 21 (1), dan Pasal 77) inkonstitusional terhadap Pasal 1(3), Pasal 28D ayat (1) dan Pasal 28I ayat (5) UUD 1945. Alasannya, ketentuan pasal-pasal tersebut telah mengabaikan hak atas kepastian hukum yang adil. Adapun naskah asli (Pasal 77) menetapkan pengadilan negeri berwenang, melalui forum praperadilan, memeriksa dan memutus: a. sah atau tidaknya penangkapan, penahanan, penghentian penyidikan atau penghentian penuntutan; b. ganti kerugian dan atau rehabilitasi bagi seorang yang perkara pidananya dihentikan pada tingkat penyidikan atau penuntutan.

Dari sudut pandang berbeda Hakim Konstitusi dapat dikatakan melalui putusannya telah mengambil alih kedudukan pembuat undang-undang dan mengubah dan menambah bunyi ketentuan Pasal 77 KUHAP tentang obyek praperadilan. $^{3}$ Melalui putusannya Mahkamah menetapkan, bahwa obyek praperadilan mencakup pula - sebagai tambahan pada ketentuan KUHAP di atas

${ }^{1}$ Putusan MK No. 17/PUU-XIII/2015 (KUHAP, hukuman mati dll.); Putusan No. 18/PUUXIII/2015 (KUHAP); Putusan MK No. 44/PUU-XIII/2015 (KUHAP); Putusan MK No. 136/PUU-XII/2014 (KUHAP, praperadilan); Putusan MK No. 120/PUU-XII/2014 (KUHAP); 67/PUU-XII/2014; Putusan MK No. 59/PUU-XII/2014 (KUHAP); Putusan MK No. 21/PUU-XII/2014 (praperadilan); Putusan MK No. 34/PUU-XI/2013 (pembatasan pengajuan PK); Putusan MK No. 68/PUU-VIII/2010 (UU 8/1981; KUHAP, Pasal 109); Putusan MK No. 41/PUU-VIII/2010 (KUHAP, Pasal 21(1), 24(2); 25(2), 26(2), 27(2), 28(2), 29(2); KUHPidana (Pasal 303(1; 2; 3) \& 303 bis $(1 ; 2)$ dan UU 7/1974 (penertiban perjudian); Putusan MK No. 22/PUU-VIII/2010 (KUHAP, Pasal 268(1) dan penjelasan).

2 Pemohon: Bachtiar Abdul Fatah: terpidana dalam kasus bio remediasi Chevron.Putusan No. 18/PUU/XII/2014. Putusan lengkap dapat diunduh di wnw.mabkamabkonstitusi.go.id/index.php? page $=$ download.Putusan.. (11/2/2015).

3 Putusan MK 21/PUU-XII/2014. Untuk ulasan umum baca Lulu Hanifah, "MK: Penetapan Tersangka Masuk Lingkup Praperadilan, 28 April 2015, dalam laman www.mahkamahkonstitusi.go.id, 6 Februari 2015. 
yang bersifat limitatif-enumeratif- penetapan tersangka, penggeledahan dan penyitaan. Di samping itu, putusan yang sama mengubah pula pengertian upaya paksa. Karena tampaknya penetapan tersangka oleh penyidik juga diperhitungkan ke dalam pengertian upaya paksa yang keabsahannya dapat diuji dalam forum praperadilan. ${ }^{4}$

Satu hal yang terbaca di balik pertimbangan-pertimbangan putusan di atas, adalah semangat MK untuk mengembangkan mekanisme pengawasan atas kinerja penyidik dalam penegakan hukum pidana. Tujuannya adalah menjaga ketertiban umum melalui penegakan hukum pidana dengan cara beradab, terkendali dan dapat dipertanggungjawabkan atau - lebih singkatterselenggaranya due processataupun fair trial, adanya proses penegakan hukum pidana yang sejalan dengan hukum dan sebab itu berkeadilan dan berwibawa.Ini pula yang akan menjadi titik tolak peneliti dalam mengkritisi putusan MK di atas. Sekalipun di sini sudut pandang yang dipilih adalah adanya asas legalitas prosesuil yang pada prinsipnya juga mengacu pada konsep negara hukum.

Pertanyaan pokok dalam penelitian ini ialah apakah MK sebagai bagian dari kekuasaan kehakiman yang mandiri berwenang menambah-mengurangi isi ketentuan hukum acara pidana? Persoalan yang sekaligus memaksa kita menelaah kembali konstelasi negara hukum (yang mengenal pemisahan kekuasaan penyelenggaraan negara) dan sistem checks and balances ala Indonesia yang justru memencarkan kekuasaan penyelenggaraan negara dalam wujud yang berbeda. ${ }^{5}$ Karena apa yang ada, pada satu pihak, adalah tuntutan akan independensi (kekuasaan) kehakiman, namun, pada lain pihak, penguatan kewenangan kekuasaan kehakiman untuk mengintervensi urusan pemerintahan (pengujian keabsahan keputusan individual konkrit melalui PTUN) dan pembuatan peraturan perundang-undangan (hak uji materiil (MA) dan hak uji konstitusional (MK)).

\footnotetext{
${ }^{4}$ Ihsanuddin, "MK Putuskan Penetapan Tersangka Termasuk Obyek Praperadilan” Kompas.com, 28 April 2015.

5 Lihat Jimly Asshiddiqie, Format Kelembagaan Negara dan Pergeseran Kekuasaan Dalam UUD 1945,Yogyakarta: FH UII Press, 2005, hlm 9-29.
} 


\section{Rumusan Masalah}

Berdasarkan uraian di atas, permasalahan yang diangkat dalam tulisan ini ialah apakah Mahkamah Konstitusi berwenang mengubah ketentuan hukum acara pidana dengan cara menyatakan beberapa pasal dalam KUHAP inkonstitusional?

\section{Tujuan Penelitian}

Penelitian ini bertujuan untuk menganalisis sejauhmana kewenangan Mahkamah Konstitusi untuk mengubah ketentuan hukum acara pidana dengan cara menyatakan beberapa pasal dalam KUHAP inkonstitusional.

\section{Metode Penelitian}

Metode penelitian yang digunakan adalah yuridis normatif. Dengan itu, dimaksudkan bahwa titik tolaknya adalah kajian tentang prinsip dan/atau norma-norma hukum acara pidana. Metode pendekatan yang digunakan yakni pendekatan kasus. Pendekatan ini digunakan untuk melihat rasio decidendi hakim konstitusi dalam Putusan MK No. 17/PUU-XIII/2015 (KUHAP, hukuman mati dll.); Putusan No. 18/PUU-XIII/2015 (KUHAP); Putusan MK No. 44/PUUXIII/2015 (KUHAP); Putusan MK No. 136/PUU-XII/2014 (KUHAP, praperadilan); Putusan MK No. 120/PUU-XII/ 2014 (KUHAP); 67/PUU-XII/2014; Putusan MK No. 59/PUU-XII/2014 (KUHAP); Putusan MK No. 21/PUUXII/2014 (praperadilan); Putusan MK No. 34/PUU-XI/2013 (pembatasan pengajuan PK); Putusan MK No. 68/PUU-VIII/2010 (UU 8/1981; KUHAP, Pasal 109); Putusan MK No. 41/PUU-VIII/ 2010 (KUHAP, Pasal 21(1), 24(2); 25(2), 26(2), 27(2), 28(2), 29(2); KUHPidana (Pasal 303(1; 2; 3) \& 303 bis (1; 2) dan UU 7/1974 (penertiban perjudian); Putusan MK No. 22/PUU-VIII/2010 (KUHAP, Pasal 268(1) dan penjelasan). 


\section{Hasil Penelitian dan Pembahasan}

\section{Asas legalitas dalam Hukum Pidana Materiil dan Hukum Pidana Prosesuil}

Asas noela poena sine praevia lege (asas legalitas) sangat penting dalam hukum pidana materiil. Asas legalitas dalam hukum pidana materiil dirumuskan sebagai nullum delictum nulla poena sine praevia lege poenali (tiada perbuatan pidana tanpa undang-undang pidana sebelumnya). Pengertian ini memuat sekaligus: 1. Nulla poena sine lege (tiada pidana tanpa ketentuan pidana menurut undangundang); 2. Nulla poena sine crimine (tiada pidana tanpa perbuatan/tindak pidana) dan 3. Nullum crimen sine poena legali (tiada perbuatan/tindak pidana tanpa pidana menurut undang-undang). Asas legalitas ini kemudian juga dapat ditafsirkan memuat syarat: larangan retroaktif, ketentuan pidana harus dirumuskan dalam wujud peraturan tertulis (lex scripta); dirumuskan secara jelas (lex certa) dan harus ditafsirkan secara ketat, termasuk ke dalamnya larangan penafsiran analogi (lex stricta). ${ }^{6}$

Warga negara dengan cara ini dilindungi dari kemungkinan penyalahgunaan kekuasaan negara. Tidak sembarang waktu penguasa dapat menyatakan sesuatu perbuatan sebagai tindak pidana dan kemudian memutuskan menindak warga karena bersalah melanggar ketetapan penguasa. Kebebasan warga melakukan/tidak melakukan sesuatu perbuatan hanya dapat dibatasi oleh dan melalui cara-cara tertentu dan bentuk tertentu: pembuatan peraturan perundang-undangan secara demokratis di mana di dalamnya termuat ketentuan pidana yang harus dirumuskan dengan tepat (lex certa). Proses demokratis inipun perlu diselenggarakan secara terbuka (transparent/transparency) dan dapat dipertanggungjawabkan (accountable). Tujuannya adalah agar masyarakat umum (yang kepentingannya sejatinya disuarakan legislatif) dapat mengerti dan memahami mengapa sesuatu perbuatan tertentu kemudian

${ }^{6}$ Baca lebih lanjut, Jan Remmelink, Hukum Pidana: Komentar atas Pasal-pasal Terpenting dari KUHP Belanda dan Padanannya dalam KUHP Indonesia, Gramedia, Jakarta, 2003, hlm. 355 et seq. Namun baca pula tulisan Loebby Loqman, "Perkembangan Asas Legalitas dalam Hukum Pidana Indonesia", (makalah disampaikan pada Seminar tentang Asas-asas Hukum Pidana Nasional, diselenggarakan oleh BPHN dan Fakultas Hukum UNDIPSemarang, 26-27 april 2004), hlm 1-9. Makalah diunduh dari http://advokasi.elsam.or.id/assets/2015/09/20040426 (11/2/2015). Di dalamnya dituliskan problematika pemahaman asas legalitas dalam perkembangan hukum pidana Indonesia yang bersumberkan pada hukum pidana Barat (tertulis) yang dibandingkan dan hukum pidana adat (tidak tertulis) 
dinyatakan sebagai terlarang dan diancamkan dengan sanksi pidana atas pelanggarannya.

Tidak terlalu terkenal - namun sama pentingnya - adalah asas serupa dalam hukum acara pidana. Asas nullum iudicium sine lege yang terangkum dalam (Pasal 3) KUHAP,7 menyatakan bahwa penegakan hukum pidana (termasuk peradilan) diselenggarakan menurut cara yang diatur dalam peraturan perundang-undangan. ${ }^{8}$ Ada dan pentingnya asas legalitas (prosesuil) dalam penyelenggaraan hukum acara pidana dilandaskan pada pertimbangan serupa: mencegah kesewenang-wenangan penguasa, in casu, pejabat penegak hukum pidana. Penegak hukum pidana yang sejatinya bekerja atas nama kepentingan umum (menjaga-memulihkan ketertiban umum yang terganggu akibat adanya tindak pidana) memiliki kewenangan yang demikian luas (upaya paksa) dan dapat jauh masuk ke dalam, termasuk mengurangi dan meniadakan, hak-hak dasar warga negara (menjatuhkan pidana termasuk pidana mati).

Dalam hal inipun, pengurangan-pembatasan termasuk peniadaan hak-hak dasar (atau kebebasan) warga negara hanya diperbolehkan bilamana hal itu dilakukan oleh penguasa melalui proses pembuatan peraturan perundangundangan yang transparan dan akuntabel. Dengan kata lain, pembatasan hak-hak dasar dari warga oleh penegak hukum pidana-demi kepentingan umum: penjagaan ketertiban umum- hanya dibenarkan (dilegitimasi) oleh proses (hukum acara) yang dirangkum (diatur-dikendalikan-dibatasi) dalam peraturan perundang-undangan dalam arti formal.Perlindungan hukum terhadap

${ }^{7}$ Untuk kritikan dan komentar terhadap perumusan asas ini di dalam KUHAP baca lebih lanjut Andi Hamzah, "Beberapa Hal dalam Rancangan KUHAP: Mengapa Perlu Menciptakan KUHAP Baru?”, makalah diajukan pada pertemuan pembahasan RUU-KUHAP di Mataram, Mei 2013, di muat di laman asosiasi advokat Indonesia: www.aai.or.id (6/2/2015).Ia menyatakan: “Ada perbedaan antara asas legalitas dalam hukum pidana materiel dan hukum acara pidana. Asas legalitas dalam hukum pidana materiel tercantum dalam Pasal 1 ayat (1) KUHP dan Rancangan KUHP. Istilah yang dipakai ialah "perundang-undangan pidana" (wettelijk strafbepaling), termasuk undang-undang, Peraturan Pemerintah dan Peraturan Daerah. Jadi, Perda dapat memuat rumusan delik dan ancaman pidana, walapun pidananya ringan. Dalam hukum acara pidana istilah yang dipakai ialah "undangundang" (wet). Jadi, tidak boleh orang ditangkap, ditahan, dituntut dst. berdasarkan PP atau PERDA. Hukum pidana materiel boleh bersifat lokal tetapi acara pidana harus bersifat nasional".

${ }^{8}$ Pentingnya asas ini dijelaskan teoretikal oleh G.J.M. Corstens, Het Nedelandse Strafprocessrecht, Arnhem: Gouda-Quint, 1993. hal. 13 et seq. Namun bandingkan dengan keraguan yang terkesan muncul dari tulisan Sidharta, "Asas Legalitas Apakah Hanya Berlaku di Ranah Hukum Material?"(15 Maret 2015), dimuat dalam laman business-lawbinus.ac.id (6/2/2015). Sekalipun iakemudian menyatakan, "asas legalitas tidak pernah mengambil jarak dengan hukum acara karena asas ini memuat pesan-pesan moral dalam berhukum. Hukum acara memuat standar perilaku dalam menjalankan hukum substantif (...). Berkat hukum acara-lah, dapat dijamin ada due process of law. Berkat hukum acara, asas similia similibus dapat ditegakan.Berkat hukum acara pula pada akhirnya bakal tercapai jenis keadilan yang disebut fairness." 
warganegara (dan kebebasan atau hak dasar yang dimilikinya), dengan demikian, harus muncul dalam bentuk pembuatan peraturan perundang-undangan tentang hukum acara pidana.

Dalam konteks itupun hukum pidana (materiil dan prosesuil) merupakan "kerangka" atau "landasan" bagi sistem peradilan pidana.Sistem peradilan pidana ini, pertumbuhan dan perkembangannya, tidak boleh diserahkan pada kebutuhan dan kepentingan praktik hukum semata. Asas legalitas dalam hukum acara pidana (nullum iudicium sine lege) - salah satu wujud pengejewantahan konsep Negara Hukum ${ }^{9}$ - justru mengindikasikan perlu dan pentingnya sistem peradilan pidana diatur melalui peraturan perundang-undangan formal (yang dibuat secara demokratis, transparan dan akuntabel). Dengan cara ini, penyelenggara Negara menjaga keseimbangan antara perlindungan hak dasar (asasi warga) dengan penegakan hukum pidana demi kepentingan umum.

\section{Mahkamah Konstitusi sebagai Organ Legislatif atau Lembaga Penguji-Pemberi Pertimbangan?}

MK menurut undang-undang pembentukannya nyata berwenang (atas dasar pengajuan permohonan) menguji secara materiil, undang-undang (tidak semua peraturan perundang-undangan) terhadap konstitusi. Adanya MK dan kewenangan (hak uji materiil) merupakan konsekuensi logis dari hierarkhi peraturan perundang-undangan yang berpuncak pada konstitusi. ${ }^{10}$ Tujuan akhirnya adalah melindungi hak konstitusional warga. Dampaknya ialah MK kemudian juga memberikan koreksi terhadap pembuatan peraturan perundangundangan produk badan legislatif. ${ }^{11}$ Jimly Asshiddiqie menulis: ${ }^{12}$

9 Untuk penggunaan konsep rule of law atau negara hokum, dalam penelitian hukum baca: Adriaan Bedner, "An Elementary Approach to the Rule of Law", Hague Journal on the Rule of Law, 2, 2010, pp. 46-74.

${ }^{10}$ Sesuai ajaran Hans Kelsen dan Nawiasky tentang stufenbau der rechtsordnung. Ajaran ini diinkorporasikan ke dalam UU 12/2011 tentang pembentukan peraturan perundang-undangan dan peraturan pelaksanaannya (PerPres 87/2014).Baca pula Ikhsan Fatah Yasin, "Teori tentang Hierarki Peraturan Perundang-Undangan" (www.academia.edu. 6/9/2015).

${ }^{11}$ Sejarah pembentukan MK dapat dirunut pada pengadopsian ide MK ke dalam UUD melalui amandemen konstitusi yang dilakukan MPR pada 2001. Gagasan ini muncul dalam Pasal 24(2), 24c, dan 7B UUD hasil perubahan ketiga (disahkan 9 November 2001). Gagasan ini kemudian dikonkritkan (sebelumnya pelaksanaannya diserahkan pada MA) dalam UU 24/2003 (pembentukan MK). Disadur dari "Sejarah Pembentukan Mahkamah Konstitusi" dari laman www.mahkamahkonstitusi.go.id (6/2/2015).

${ }^{12}$ Jimly Asshiddiqie, "Kedudukan Mahkamah Konstitusi dalam Struktur Ketatanegaraan Indonesia", dalam laman www.jimlyschool.com (6/2/2015). Di dalam UU 24/2003 lingkup kewenangan MK serupa dituliskan lebih ringkas (Pasal 10): pengujian UU terhadap UUD Negara Republik Indonesia tahun 1945; 
“(..) MK mempunyai kedudukan yang sederajat dengan dan sama tinggi dengan MA. [keduanya: pen] merupakan pelaksana cabang kekuasaan kehakiman (judiciary) yang merdeka dan terpisah dari cabang-cabang kekuasaan lain, yaitu pemerintah (executive) dan lembaga permusyawaratanperwakilan (legislature). (...) Mahkamah Konstitusi tidak berurusan dengan orang per orang, melainkan dengan kepentingan umum yang lebih luas.Perkara-perkara yang diadili di MK pada umumnya menyangkut persoalan-persoalan kelembagaan negara atau institusi politik yang menyangkut kepentingan umum yang luas ataupun berkenaan dengan pengujian terhadap norma-norma hukum yang besifat umum dan abstrak, bukan urusan orang per orang atau kasus demi kasus ketidakadilan secara individual-konkrit."

Dalam perjalanan waktu, MK tidak hanya memutus suatu undang-undang inkonstitusional atau tidak, melainkan juga melakukan lebih dari itu.Tercatat bahwa MK, secara langsung, memberikan rumusan pengertian yang lebih tegas terhadap sejumlah konsep yang menjadi persoalan pokok dalam undang-undang yang dipersoalkan.Misalnya terhadap pengertian dan luas lingkup konsep hak menguasai negara dalam pengujian UU Sumberdaya Air, Tenaga Listrik dstnya), atau memberikan pengertian baru terhadap hutan negara. Pasca putusan MK hutan negara tidak lagi mencakup hutan (hak) adat. Di samping itu, MK melalui putusannya tidak hanya meniadakan keberlakuan sebagai hukum pasal-per pasal ketentuan perundang-undangan (UU Notaris, KUHP, KUHAP; praperadilan I), namun justru keseluruhan paket perundang-undangan produk badan legislatif (UU BHP, SKK MIGAS).13 Bahkan MK pernah pula memeriksa dan harus memutus persoalan apakah perjanjian internasional yang sudah diratifikasi Indonesia (dan artinya dari sudut pandang hukum perjanjian internasional) sudah enter into force dan berlaku sebagai hukum yang mengikat, sesuai dengan konstitusi (UU Ratifikasi ASEAN yang sekaligus memberlakukan Asean Free Trade Area) selaras dengan UUD 1945. ${ }^{14}$ Alasan yang diajukan pemohon in casu adalah

sengketa kewenangan lembaga negara yang kewenangannya diberikan oleh UUD 1945; pembubaran partai politik; perselisihan tentang hasil pemilihan umum; atau (memberikan penilaian atas) pendapat DPR tentang perilaku Presiden/wakil presiden dalam proses pemakzulan.

13Putusan-putusan MK tersebut dapat diperoleh dengan mudah dalam laman resmi MK:www.mahkamahkonstitusi.go.id/index.php

${ }^{14}$ Putusan MK no. 33/PUU-IX/2011 (pengujian undang-undang UU 38/2008 tentang pengesahan Charter of the Association of Southeast Asian Nations). Pertanyaan yang kemudian muncul ialah apakah betul MK memiliki kewenangan untuk menguji "perjanjian internasional" yang telah diratifikasi (disahkan dan diberlakukan sebagai hukum positif) oleh parlemen-pemerintah terhadap UUD 1945? Ini dikatakan dengan memperhatikan pertimbangan MK [3.9, hal 186 dari 205] yang menyatakan: (...) oleh karena Mahkamah berwenang mengadili 
bahwa pemberlakuan pasar bebas akan mengancam pemenuhan hak-hak sosial ekonomi masyarakat.

Titik tolak MK ketika memutus itu semua ialah tugas dan tanggungjawabnya sebagai guardian of the constitution.Dalam kedudukannya itu, MK wajib menjaga agar setiap tindakan legislatif tidak melanggar hak-hak konstitusional warga. Sebab itulah, maka MK "demi hukum" berwenang memutuskan (dan dengan itu membatalkan atau meniadakan keberlakuan hukum) ketentuan-ketentuan yang diperiksa, bahkan seluruh undang-undang, bertentangan dengan konstitusi atau (berpotensi) melanggar hak konstitusional warga-negara.

Dari sudut pandang lain, dapat dikatakan bahwa sebenarnya MK melangkah lebih jauh daripada sekadar memutus suatu undang-undang konstitusional atau inkonstitusional. Putusan-putusan MK, sebagai kekuasaan kehakiman yang mandiri, ternyata tidak hanya memuat perintah untuk membatalkan (tidak menganggap suatu undang-undang memiliki kekuatan hukum) melainkan lebih dari itu, dalam beberapa putusan, memuat pula amar putusan yang secara substantif mengubah, menambah-mengurangi ketentuan perundang-undangan yang termuat dalam undang-undang (sejatinya sudah dibuat melalui proses demokrasi yang akuntabel dan transparan) yang dalam pertimbangannya tidak sejalan dengan konstitusi. ${ }^{15}$

Putusan MK sebagai ikthiar constitutional review - berangkat dari gagasan berbeda - tentu tidak dapat begitu saja dapat diperbandingkan dengan bagaimana yurisprudensi dan doktrin (dalam praktik hukum) mengembangkan, mengisi, mengubah dan mengurangi ketentuan perundang-undangan.Beranjak dari itu, di

permohonan a quo dan para pemohon memiliki kedudukan hukum (legal standing) untuk mengajukan permohonan a quo, (...). Untuk kritikan baca: ASH, "Pengujian UU Ratifikasi Piagam ASEAN Kandas, hukumonline.com, 26 februari 2013. Disebutkan bahwa MK hanya melakukan pengujian formil tidak materiil. Bandingkan pula dengan tulisan Damos Dumoli Agusman, "Keputusan Mahkamah Konstitusi tentang Piagam ASEAN: Arti Penting bagi Nasib Perjanjian Lainnya”, Opinio Juris, Vol. 13 Mei-Agustus 2013: 16-21. Ia justru mengkritik pertimbangan bahwa MK wenang menguji perjanjian internasional dari sudut pandang hukum internasional publik.

15 Pertanyaan berkenaan dengan kewenangan hakim untuk tidak sekadar menaati peraturan perundangundangan, namun juga membatalkan perundang-undangan atas nama kepentingan umum (hakim sebagai wakil/suara rakyat) dibahas dalam konteks counter-majoritarian dilemma. Periksa: Daniel J.H. Grenwood, "Beyond the Counter-Majoritarian Difficulty: Judicial Decision-Making in a Polynomic World", (Rutgers Law Review, Vol. 53, Summer 2001, No. 4): pp.781-862. Namun bdgkan juga dengan Mark A. Graber, "The Countermajoritarian Difficulty: From Courts to Congress to Constitutional Order", Annu. Rev.Law.Soc. Sci. 2008. 4:361-84. 
sini kita dapat membandingkan dua kegiatan penemuan hukum yang berangkat dari titik tolak berbeda.Peraturan perundang-undangan (yang tidak mungkin lengkap dan sempurna) meniscayakan penemuan hukum yang dari sudut pandang ilmu hukum dianggap wajar dan perlu. ${ }^{16}$ Pertanyaannya di sini, apakah MK juga berwenang atau dipersiapkan melakukan hal serupa (penemuan hukum) untuk semua bidang hukum khusus?Ataukah MK yang melakukan constitutional review hanya berwenang menguji dan menyatakan suatu undangundang selaras atau tidak selaras dengan konstitusi? Bagaimanapun juga pada akhirnya MK melalui putusan-putusannya "memaksakan" pembacaan bunyi ketentuan peraturan perundang-undangan bahkan suatu bidang hukum dengan cara tertentu. ${ }^{17}$

Dalam konteks constitutional review, putusan MK yang membatalkan suatu peraturan perundang-undangan dapat dipandang sebagai masukan pertimbangan bagi parlemen dan/atau pemerintah (legislatif) untuk memperbaiki atau membuat ulang peraturan perundang-undangan yang harus dibuat sejalan dengan konstitusi. ${ }^{18}$ Menjadi pertanyaan, apakah tidak akan lebih efisien dan efektif bilamana MK difungsikan untuk memberikan pertimbangan sebelum peraturan perundang-undangan disahkan dan diberlakukan. Artinya MK difungsikan untuk memberikan preview bukan review pasca diberlakukannya ketentuan peraturan perundang-undangan sebagai hukum positif. Alasan yang dapat dikemukakan di sini berkaitan dengan penghematan anggaran negara. Karena membatalkan satu paket perundang-undangan merupakan pemborosan keuangan negara. Pertama, anggaran yang sudah dikeluarkan untuk membuat satu paket perundang-undangan (dan sekian banyak peraturan pelaksanaan)

16 Paul Scholten, "De Structuur der Rechtswetenschappen”, dalam G.J. Scholten, Y. Scholten, M.H. Bregstein, Verzamelde Geschriften van wijlen Prof. Mr. Paul Scholten, deel I, Zwolle: Tjeenk-Willink, 1949; J.J.H. Bruggink, Refleksi tentang Hukum, diterjemahkan Bernard Arief Sidharta, Bandung: Citra Aditya Bakti, 1996; Bernard Arief Sidharta, Ilmu Hukum Indonesia: Upaya Pengembangan Ilmu Hukum Sistematik yang Responsif terbadap Perubahan Masyarakat, Bandung: Genta Publishing, 2013.

${ }^{17}$ Lihat, misalnya, Asosiasi Pengusaha Indonesia \& International Labour Organization, Buku Kompilasi Putusan Mabkamah Konstitusi tentang Uji Materi terbadap beberapa pasal pada Undang-Undang No. 13 Tahun 2003 tentang Ketenagakerjaan, 2014. Termuat dalam laman www.ilo.org (6/9/2015)

${ }^{18}$ Untuk bahasan tentang pentingnya judicial review oleh MK, baca: Jimly Asshiddiqie, "Sejarah Constitutional Review dan Gagasan Pembentukan Mahkamah Konstitusi", The Three "E" Lectures Series, @ merica, Pacific Place, Level 3, Jakarta, Senin 18 Juni 2012, dimuat dalam laman http://jimlyschool.com $(6 / 3 / 2015)$. 
menjadi sia-sia, dan kedua, selanjutnya harus disediakan anggaran baru untuk memulai proses pembuatan undang-undang baru.

Sebagaimana telah disinggung di atas, ditengarai MK menggunakan dan menafsirkan kewenangannya lebih dari sekadar menguji dan mengoreksi. MK dalam kasus pengujian KUHAP (ketentuan tentang pembatasan gugatan praperadilan) terhadap konstitusi, memutus bahwa terhadap aturan di dalam KUHAP harus ditambahkan aturan lain yang menetapkan penetapan tersangka sebagai obyek praperadilan. Di samping itu, juga di dalam putusan yang sama, MK menetapkan bahwa penetapan tersangka haruslah didasarkan pada minimal dua alat bukti. ${ }^{19}$ Artinya definisi KUHAP20 tentang tersangka harus dibaca berbeda: tersangka adalah seorang yang (karena perbuatannya atau keadaannya), berdasarkan sekurang-kurangnya dua alat bukti (tidak lagi bukti permulaan), patut diduga sebagai pelaku tindak pidana. Alhasil hakim tunggal (praperadilan) seolah-olah diberikan kewenangan menguji keabsahan (tidak hanya secara formil namun juga materiil keabsahan) dua alat bukti. Pembacaan seperti ini membawa konsekuensi bahwa persangkaan adanya tindak pidana (pokok perkara) diuji kebenarannya tidak di forum pengadilan (yang harus memutus adanya kesalahan dan kemampuan bertanggungjawab dari terdakwa), namun justru di praperadilan.

MK di sini (dan kiranya juga dalam banyak putusan lain) menggantikan sepenuhnya posisi pembuat undang-undang dan dengan itu secara nyata melanggar asas legalitas prosesuil. Tentu dapat diajukan pembelaan bahwa pemeriksaan perkara dihadapan MK dilakukan secara transparan dan akuntabel. Selanjutnya, bahwa putusan MK sudah cukup dilandaskan pada pertimbanganpertimbangan yang dapat dipertanggungjawabkan secara rasional (voldoende gemotiveerd). Satu hal yang namun demikian tidak terpenuhi adalah syarat pembuatan aturan yang dilakukan secara demokratis, transparan dan akuntabel.

Tidak sekaligus hendak disangkal pentingnya monitoring-pengawasan dan evaluasi kerja dari penegak hukum pidana dalam konteks due process dan/atau

19 "Polri Hormati Putusan MK tentang Penetapan Tersangka Minimal 2 Alat Bukti", 15 Mei 2015, dalam laman www.mahkamahkonstitusi.go.id (6/2/2015).

20 Ketentuan Pasal 1 angka 1 KUHAP: seorang yang karena perbuatannya atau keadaannya, berdasarkan bukti permulaan, patut diduga sebagai pelaku tindak pidana. 
penjagaan fair trial. Kiranya hal ini juga mewarnai pertimbangan MK. Di dalam putusan yang memperluas luas lingkup praperadilan, MK antara lain mempertimbangkan bahwa penyidik memiliki serangkaian tindakan (upaya paksa: pen) mengurangi hak asasi manusia seseorang atas nama negara. ${ }^{21}$ Penetapan tersangka, dalam hal ini dipersamakan dengan upaya paksa, dipandang terbuka bagi tindakan sewenang-wenang terhadap mana tersangka demi prinsip hak atas kepastian hukum yang adil - maka kepada warga yang ditetapkan sebagai tersangka harus diberikan kesempatan mengajukan perlawanan dalam wujud pengajuan praperadilan.

Terlepas dari sejumlah kesesatan berpikir (fallacy karena menyamakan dua hal yang tidak sebanding: tidak terpenuhinya prinsip similia similibus), 22 yaitu penyetaraan penetapan sebagai tersangka sebagai upaya paksa, penulis sependapat bahwa dalam (praktik) hukum acara pidana, kewenangan penyidik nyata sedemikian besar sehingga dan dapat masuk jauh mengurangi dan melanggar hak asasi manusia (hak dasar atau kebebasan). Selanjutnya, harus diakui bahwa kewenangan penyidik betul dengan mudah dapat disalahgunakan. Namun, penulis tidak tidak sertamerta sepakat bahwa penyelesaiannya harus ada pada perluasan lingkup praperadilan dengan sebagaimana diputus oleh MK.

Persoalan yang tersembunyi dibalik riuh-rendahnya perdebatan tentang pentingnya praperadilan bagi pengujian keabsahan penetapan tersangka adalah bagaimana kita harus mengawasi kerja kepolisian sebagai pejabat penyidik serta bagaimana melindungi warganegara terhadap kemungkinan aparat penyidik menyalahgunakan kewenangan yang ada padanya. Di samping itu, dikesampingkan pula alasan mengapa sebenarnya praperadilan pada praktiknya tidak berdaya-guna, hal mana tidak sertamerta terjawab dengan memperluas

21 Benny Sabdo, "Kepastian Hukum yang Adil" 13 mei 2015 dimuat dalam laman www.mahkamahkonstitusi.go.id (6/2/2015).

${ }^{22}$ Lihat, antara lain, Antonios Emmanuel Platsas, "The Functional and the Dysfunctional in the Comparative Method of Law: Some Critical Remarks, Electronic Journal of Comparative Law, vol 12.3. December 2008, http://www.ejcl.org.Ia menyatakan: "the comparatist will always be haunted by this memorable and magical expression: 'incomparables cannot usefully be compared'. (...) It is like for like (similia similibus) that normally suffices in comparing". 
kewenangan praperadilan oleh MK. Sebagaimana dituliskan tim peneliti dari Institute for Criminal Justice Reform:23

“Penyidik dan penuntut juga acapkali resisten dengan penggunaan mekanisme Praperadilan oleh tersangka/terdakwa. Sering ditemui ketika diketahui suatu kasus diajukan Praperadilan, biasanya penyidik akan mempercepat proses pemeriksaan agar perkara pokoknya bisa segera dilimpahkan ke pengadilan, sehingga upaya Praperadilan gugur. Kurangnya itikad baik dari penyidik dalam penggunaan mekanisme Praperadilan, ditunjukkan pula dari keengganan penyidik untuk menghadiri sidang Praperadilan, sehingga berakibat pada lambatnya penanganan perkara Praperadilan, padahal waktunya sangat singkat. (...) Pengadilan sendiri mengakui ada banyak kendala dalam Praperadilan, selain ketidaklengkapan peraturan, "keharusan" menjaga hubungan baik dengan penyidik dan penuntut juga menjadi pertimbangan."

Cara pandang ini sekaligus membebaskan kita dari jebakan berpikir dikotomis yang melingkupi perdebatan tentang luas lingkup pra peradilan: prokontra cicak-buaya atau mendukung-tidak mendukung POLRI atau bahkan anti atau pro Putusan MK. Sebagaimana dijelaskan di bagian awal titik tolak yang digunakan adalah pengakuan penting dan perlunya monitoring dan evaluasi dari pelaksanaan kewenangan penyidik yang begitu luas dan sebab itu juga begitu mudah untuk disalahgunakan.

\section{Pentingnya Pengawasan dan Evaluasi terhadap Penggunaan Upaya Paksa}

Pentingnya persoalan di atas dapat diilustrasikan dengan mencermati tugas penyidik dalam arti luas (termasuk ke dalamnya kepolisian): pejabat penegak hukum pidana yang langsung berurusan dengan gangguan terhadap ketertiban umum yang dimunculkan (dugaan) adanya tindak pidana apapun juga. Pejabat penyidik, sesuai lingkup tugas dan kewenangannya, dapat mempertimbangkan, memutuskan dan menetapkan seseorang sebagai orang yang patut dicurigai melakukan tindak pidana (tersangka) dan berdasarkan itu memulai tindakan penyelidikan-penyidikan. Dalam rangka kedua kegiatan itu: penyelidikan atau penyidikan, penegak hukum pidana berwenang menerapkan sejumlah upaya paksa: memberhentikan seseorang, menggeledah, menyita,

23 Anggara dkk, Naskah Akademik dan Rancangan Peraturan Mahkamah Agung tentang Hukum Acara Praperadilan, Jakarta: ICJR, desember 2014. Dalam laman www.icjr.or.id, 6 September 2015. 
termasuk mengintai, menyadap, menangkap, menahan, dan seterusnya. Semua upaya paksa tersebut jelas mengurangi bahkan meniadakan sejumlah kebebasan atau hak-hak dasar warga negara.

Di sini jelas diperlukan kontrol yang ketat atas penggunaan kewenangan yang dimiliki pejabat penyidik (penegak hukum pidana) tersebut. Penetapan sebagai tersangka (berdasarkan bukti permulaan cukup) atau semata-mata sebagai target operasi penyelidikan-penyidikan yang melandasi keputusan untuk mendayagunakan atau tidak mendayagunakan upaya paksa jelas dapat disalahgunakan. Dalam hal ini kita berbicara tentang penyalahgunaan kewenangan (abuis de poivoir). Dengan kata lain, suatu kewenangan tertentu yang diberikan kepada penegak hukum pidana ternyata digunakan untuk mencapai maksud-tujuan yang berbeda daripada yang sebenarnya melandasi adanya pemberian kewenangan tersebut.Sekaligus kita bersentuhan dengan pentingnya menerapkan criterium asas-asas umum pemerintahan yang baik ${ }^{24}$ (kepercayaan, dll) terhadap penegak hukum yang tidak saja memiliki kewenangan berdasarkan aturan perundang-undangan, namun juga memiliki diskresi untuk menggunakan atau tidak menggunakan kewenangan tersebut ketika mereka menjalankan fungsi penegakan hukum (pidana).

In concreto, seorang penyidik dapat memberitahukan seseorang (mungkin dengan bukti permulaan yang cukup atau dua alat bukti yang sah) bahwa ia menjadi obyek penyelidikan-penyidikan. Namun yang dilakukan kemudian adalah "memeras" tersangka untuk membayar sejumlah uang agar statusnya sebagai orang yang dicurigai bersalah dapat dihapuskan. Penyalahgunaan lain yang juga terdengar diam-diam sekalipun tidak pernah dituliskan ialah "penetapan" sebagai tersangka sekelompok orang (mahasiswa) yang sedang berpesta. Setelah tertangkap tangan, mereka ditahan dan ditetapkan sebagai tersangka atas dugaan menyalahgunakan obat-obatan terlarang.Namun bukannya memproses sesuai ketentuan perundang-undangan, penyidik menggunakan para tersangka sebagai sandera yang ditawarkan untuk ditebus

${ }^{24}$ Tertuang dalam UU 28/1999 tentang Penyelenggaraan Negara yang Bersih dan Bebas KKN. Di dalam UU 28/1999 dirinci ke dalam 1. Asas kepastian hukum; 2. Asas tertib penyelenggaraan negara, 3.Asas kepentingan umum; 4. Asas keterbukaan; 5. Asas proporsionalitas; 6. Asas profesionalits; 7.Asas akuntabilitas. Di dalamnya tercakup pula asas-asas lain asas persamaan, kepercayaan, kepastian hukum, kecermatan, pemberian alasan, larangan penyalahgunaan kewenangan, larangan willekeur (bertindak semena-mena). 
per kepala. Mereka yang membayar sesuai harga-tentu di bawah meja - akan dilepas dan kasusnya "dipeti-eskan".

Pernah juga terdengar, seorang penyidik mendatangi sebuah pabrik tekstil dan menyatakan (tanpa dukungan alat bukti yang cukup) bahwa direktur pabrik yang bersangkutan telah melanggar ketentuan tentang pengolahan limbah cair (tindak pidana lingkungan).Dalam kasus inipun "penetapan" sebagai tersangka diselesaikan secara transaksional.

Selain dari apa yang telah dipaparkan di atas, dan hal ini kemungkinan besar yang menjadi persoalan utama, penetapan tersangka digunakan demi pencapai tujuan-tujuan politik atau ekonomi atau sekadar demi mempertahankan harga diri. Maka menetapkan seorang sebagai tersangka-dengan mengajukan laporan dan mendorong penyidik menggunakan upaya paksa yang ada padanya - dapat dipahami sebagai satu strategi ampuh yang dapat digunakan seseorang (atau lembaga) untuk mencapai tujuan-tujuan politik-ekonomi atau setidaktidaknya tujuan lain di luar penegakan hukum pidana. Dapat ditengarai fenomena penggunaan pelaporan penipuan-penggelapan untuk membereskan persoalan utang-piutang.Harapannya adalah dengan campur-tangan polisi yang dapat diminta 'menangkap-menahan' atau menetapkan seseorang (debitur) sebagai tersangka, utang dari transaksi bisnis yang tertunda akan segera dilunasi.

Juga kerap muncul laporan pencemaran nama baik yang berujung pada proses pemeriksaan oleh polisi yang menguras tenaga-waktu-biaya terlapor. Pihak Rumah Sakit Omni yang melaporkan Prita Mulyasari yang menulis kritikan di media sosial merupakan contoh aktual tentang ini. Kemungkinan besar pihak pengelola RS tersinggung dan memutuskan membela harga diri dan nama baik dengan melaporkan Prita kepada polisi. ${ }^{25}$ Kasus lain dengan nuansa politik yang kental berkaitan dengan penetapan sebagai tersangka korupsi pejabat-pejabat tinggi negara (sipil-kepolisian-militer). Pembelaan yang kemudian muncul ialah bahwa proses penyidikan sengaja dilakukan untuk mencapai tujuan-tujuan

25 “Prita Mulyasari Dinyatakan Tak Bersalah" www.tempo.co, 17 september 2012. (6/10/2015). 
politik-ekonomi. Kasus Cicak (KPK)-Buaya (Kepolisian) dapat dipahami dalam konteks ini. ${ }^{26}$

Dalam contoh-contoh di atas tersembunyi sejumlah persoalan: pertama, apakah tersedia criterum baku yang dapat digunakan untuk menetapkan seseorang sebagai tersangka (dan kemudian terdakwa); kedua, bagaimana memastikan keabsahan penggunaan upaya-upaya luar biasa (mengintai, menyelidiki, menyadap, penyamaran, dll.) serta upaya paksa (menangkap, menahan, menggeledah, dll) yang diberikan kepada penyelidik-penyidik; dan ketiga, bagaimana mencegah penyalahgunaan penetapan sebagai tersangka. Penyalahgunaan di sini, dengan merujuk contoh-contoh di atas, diartikan secara luas dalam arti penetapan sebagai tersangka digunakan bukan untuk mencapai maksud-tujuan yang ditetapkan hukum pidana: mengungkap-menemukan kebenaran atau menjatuhkan putusan yang adil.

Berkenaan dengan keabsahan/ketidakabsahan penggunaan upaya paksa, betul sudah tersedia kontrol dalam wujud pengujian melalui forum praperadilan.Dalam lembaga, sesuai penamaannya, praperadilan, seharusnya hakim (tunggal) tidak memeriksa pokok perkara (dan menguji dengan mengikuti hukum pembuktian yang berlaku, kebenaran/ketidakbenaran materiil dari alatalat bukti yang tersedia). Namun sebaliknya, hakim dalam pra-peradilan hanya memeriksa dan menguji ikhwal keabsahan penerapan upaya paksa serta penghentian penyidikan atau penuntutan.

Konsekuensi dari hal tersebut adalah, untuk sejumlah upaya paksa, seharusnya tersedia mekanisme pengawasan dan kontrol: sebelum melakukan penggeledahan atau penangkapan-penahanan (yang melanggar hak dan kebebasan warga), penyidik harus mendapatkan - persetujuan tertulis dari ketua pengadilan negeri. Secara substantif tentu penyidik yang dapat menilai perlu tidaknya dilakukan penggeledahan (untuk mencari barang bukti) atau untuk menangkap-menahan saksi/tersangka (mencegahnya melarikan diri atau menghilangkan barang bukti), namun penilaian atas keabsahannya secara prosedural (dan artinya kontrol) diserahkan pada instansi di luar lembaga

26 "Perbedaan "Cicak vs Buaya" Jilid 3 dengan Jilid 1 dan 2",www.kompasiana.com, 23 Januari 2013, 6 Oktober 2015. 
penyidik.Persetujuan ini harus diperoleh sebelum upaya paksa direalisasikan.Atau dalam hal penangkapan-penahanan segera setelah upaya paksa digunakan.Ada/tidaknya persetujuan dan apakah upaya paksa dilakukan dengan cara-cara yang melanggar hukum selanjutnya dapat diuji di dalam proses pemeriksaan pra-peradilan.Keberhasilan mekanisme ini dengan demikian tergantung pula pada pengetahuan serta kemampuan terdakwa (atau pembela) untuk menggunakannya.

Persoalan yang kendati demikian diangkat oleh pemohon yang kemudian diputus MK berkenaan dengan lingkup jangkauan pra-peradilan yang dianggap sangat limitatif (tidak mencakup penggeledahan-penyitaan) dan sebab itu dianggap bertentangan dengan konstitusi.

\section{Penetapan sebagai Tersangka sebagai Masalah Hukum Acara atau Penyalahgunaan Kewenangan?}

Lantas bagaimana dengan penetapan sebagai tersangka? Di atas sudah dicontohkan betapa mudahnya penyidik menyalahgunakan penetapan tersangka untuk tujuan lain di luar kepentingan pencarian kebenaran dan penegakan keadilan. Instansi manakah yang seharusnya mengawasi keabsahan penetapan tersangka oleh polisi atau berdasarkan banyak undang-undang khusus: oleh Komisi Pemberantasan Korupsi (KPK), Kejaksaan Tinggi atau Penyidik Pegawai Negeri Sipil (PPNS) yang memiliki kewenangan menyidik delik-delik khusus di luar KUHP?

Umumnya kita akan berbicara tentang adanya bukti permulaan yang cukup tentang dugaan telah terjadi tindak pidana berdasarkan KUHAP, Pasal layat 14; 17; dan 21. Ad informandum, sebagai perbandingan, ketika berbicara tentang penetapan tersangka (verdachte), Corstens menggunakan tiga criterium materiil: adanya tindak pidana (asas legalitas dalam hukum pidana materiil); adanya dugaan masuk akal adanya kesalahan pada pelaku (redelijk vermoeden van schuld); dugaan masuk akal tersebut harus berlandaskan fakta atau situasi-kondisi (feiten of omstandigheden). ${ }^{27}$ Dalam sistem peradilan pidana Belanda, penetapan tersangka dipandang sebagai awal dari penggunaan sejumlah upaya paksa oleh

\footnotetext{
${ }^{27}$ Corstens, Op.Cit, hlm. 82-84.
} 
penyidik.Sedangkan kerja polisi yang diawali dari penetapan seorang sebagai tersangka diawasi secara ketat oleh, antara lain, rechter commissaris dan OM (Openbaar Ministerie-Kejaksaan).

Kembali pada proses atau cara pidana di Indonesia, apa yang ada sebelum lingkup obyek pra-peradilan diperluas adalah proses pelimpahan perkara yang dapat berujung pada P-21, yaitu diterima untuk diproses menjadi dakwaan dan diserahkan kepada pengadilan untuk diperiksa, dan P-19, yaitu dikembalikan dengan catatan: kurangnya alat bukti. Dalam proses pelimpahan perkara, jaksa yang tidak memimpin sendiri proses penyidikan, terkecuali untuk tindak pidana khususakan menilai apakah status tersangka dapat ditingkatkan menjadi terdakwa. Untuk itu akan diperiksa dan dinilai apakah alat-alat bukti yang ada hasil olahan pihak penyidik sudah memadai untuk membuktikan adanya tindak pidana serta salahnya terdakwa (dapat dipertanggungjawabkan perbuatan pada terdakwa). Dalam proses bolak-balik ini baik penyidik maupun kejaksaan dapat memutuskankurangnya alat bukti yang sah serta berdasarkan itu menetapkan penghentian penyidikan atau penuntutan (SP3). Sebaliknya, jaksa atau kepolisian juga dapat memutus, menghadapi kurangnya alat bukti, untuk mencari dan melengkapi alat bukti yang diperlukan.

Dari sudut pandang prosedur yang digambarkan di atas, putusan praperadilan yang menetapkan tidak sahnya penetapan tersangka sebagai mekanisme pengawasan keabsahan penetapan tersebut menjadi janggal dan salah sasaran. Pertama, apakah betul perlu ada penetapan dalam wujud surat keputusan sebelum seseorang ditetapkan sebagai target operasi penyidikan? Bukankah pengawasan yang justru diperlukan adalah terhadap keabsahan penggunaan upaya paksa: penangkapan-penahanan misalnya. Di samping itu, pengawasan juga harus dilakukan terhadap ketaatan penyidik atas etika dan profesionalitas penegak hukum. Karena ketika mereka (penyidik) menyalahgunakan kewenangan untuk menetapkan status seseorang sebagai tersangka, mereka bersalah melanggar kode etik profesi maupun aturan hukum pidana (pemerasan). Betulkah forum pra-peradilan dengan lingkup putusan yang sangat terbatas dapat difungsikan secara efektif untuk mencegah penyalahgunaan kewenangan yang digambarkan di atas? 
Kedua, pernyataan tidak sahnya penetapan tersangka oleh pra-peradilan tidak dapat dan boleh dimaknai sebagai putusan bebas. Tidak serta merta, bilamana putusan pra-peradilan menyatakan tidak sahnya penetapan sebagai tersangka, keseluruhan kerja penyidikan menjadi tidak sah dan alat-alat bukti yang telah dikumpulkan susah payah otomatis dinyatakan tidak sah. Bukankah putusan tidak sahnya penetapan tersangka seharusnya hanya berartipenetapan tersebut belum memenuhi kriteria adanya cukup alat bukti. Padahal proses pengawasan ini seharusnya masuk ke dalam lingkup tugas Jaksa. Lagipula tidak turut dinilai, dalam proses pra-peradilan, adalah keabsahan bukti-bukti yang ada, hal mana baru akan dipersoalkan di sidang pengadilan.

Selanjutnya ketika putusan pra-peradilan menetapkan tidak sahnya penetapan sebagai tersangka, apakah hakim tunggal pra-peradilan juga berwenang memutuskan penghentian penyidikan yang sedang berjalan? Konsekuensi hukum dari itu adalah tidak terbuktinya tindak pidana yang bahkan belum diperiksa dan dibuktikan kebenaran/ketidakbenarannya dihadapan pengadilan. Persoalan yang muncul karena pasca putusan hakim Sarpin, kasus yang ada diperlakukan bukan lagi sebagai tindak pidana melainkan sekadar dugaan mal-administrasi yang dapat diselesaikan secara internal melalui rapat kerja.

Kesemua di atas tidak hendak menafikan perlunya pengawasan terhadap kerja polisi.Ancaman penyalahgunaan kewenangan menetapkan seseorang sebagai tersangka tidak dapat dipungkiri. Persoalannya - sekadar menggarisbawahi - adalah apakah forum pra-peradilan merupakan sarana tepat guna untuk itu.

\section{Penutup}

Berdasarkan kajian atas permasalahan di atas, dapat disimpulkan bahwa ketika MK dalam pengujian KUHAP memutus memperluas lingkup praperadilan, atas dasar KUHAP bertentangan dengan konstitusi, MK sebenarnya sudah mengambilalih peran pembuat undang-undang, dan dengan itu melanggar 
asas legalitas prosesuil. Selain itu, apa yang disuarakan dalam putusan MK adalah kekhawatiran masyarakat umum akan penyalahgunaan kewenangan polisi dalam penetapan seseorang sebagai tersangka. Solusi yang ditawarkan dalam putusan MK adalah mengubah kriterium tersangka dan itu justru memunculkan ketidakpastian bagi penyelenggaraan, kelancaran dan kecepatan penegakan hukum pidana.

Padahal, dari sudut pandang lain, dengan melakukan perbandingan hukum, sebenarnya dapat kita temukan banyak solusi lain yang dapat diujicobakan di Indonesia dalam rangka mengembangkan sistem dan mekanisme pengawasan yang dapat mencegah penyalahgunaan kewenangan prosesuil yang diberikan kepada aparat penegak hukum.Terobosan hukum yang diujicobakan di Indonesia, yaitu memperbaiki sistem peradilan pidana dengan melanggar asas legalitas prosesuil jelas tidak dianjurkan.

\section{Daftar Pustaka}

Agusman, Damos Dumoli, “Keputusan Mahkamah Konstitusi tentang Piagam ASEAN: Arti Penting bagi Nasib Perjanjian Lainnya", Opinio Juris, Vol. 13 mei-agustus 2013.

Anggara, dkk., Naskah Akademik dan Rancangan Peraturan Mahkamah Agung tentang Hukum Acara Praperadilan, Jakarta: ICJR, desember 2014. Dalam laman www.icjr.or.id (6/9/2015).

Anonimus, "Polri TNI Pisah" Apakah Suatu Kesalahan, www.kompasiana.com 12 april 2013 (6/10/2015).

_. "Sejarah Pembentukan Mahkamah Konstitusi" dari laman www.mahkamahkonstitusi.go.id (6/2/2015).

"Polri Hormati Putusan MK tentang Penetapan Tersangka Minimal 2 Alat Bukti", 15 mei 2015, dalam laman www.mahkamahkonstitusi.go.id (6/2/2015).

_ "Perbedaan "Cicak vs Buaya" Jilid 3 dengan Jilid 1 dan 2",www.kompasiana.com.23 Januari 2013 (6/10/2015).

, "Prita Mulyasari Dinyatakan Tak Bersalah"www.tempo.co, 17 september 2012. $(6 / 10 / 2015)$

ASH, "Pengujian UU Ratifikasi Piagam ASEAN Kandas, www.hukumonline.com. 26 Februari 2013. 
Asosiasi Pengusaha Indonesia \& International Labour Organization, Buku Kompilasi Putusan Mahkamah Konstitusi tentang Uji Materi terhadap beberapa pasal pada Undang-Undang No. 13 Tahun 2003 tentang Ketenagakerjaan, 2014. Termuat dalam laman www.ilo.org (6/9/2015).

Asshiddiqie, Jimly, Format Kelembagaan Negara dan Pergeseran Kekuasaan Dalam UUD 1945, FH UII Press, Yogyakarta, 2005.

"Kedudukan Mahkamah Konstitusi dalam Struktur Ketatanegaraan Indonesia", dalam laman www.jimlyschool.com (6/2/2015).

, "Sejarah Constitutional Review dan Gagasan Pembentukan Mahkamah Konstitusi", The Three "E" Lectures Series, @merica, Pacific Place, Level 3, Jakarta, Senin 18 juni 2012, dimuat dalam laman http://jimlyschool.com $(6 / 3 / 2015)$.

Batiza, Rodolfo, "The French Revolution and Codification: Comment on the Enlightment, The French Revolution, and the Napoleonic Codes, 18 Vol. U.L.Rev. 675 (1984) available at http://scholar.valpo.edu/vulr/ vol18/iss3/6. (6/2/2015);

Bedner, Adriaan, "An Elementary Approach to the Rule of Law", Hague Journal on the Rule of Law, 2, pp. 46-74. Doi:10.1017/S1876404510100037. (6/2/2015), 2010.

Borgers, M.J., \& L. Stevens, "The Use of Illegally Gathered Evidence in the Dutch Criminal Trial", www.ecjl.org/143/art143-4.doc.; (6/2/2015)

Bruggink, J.J.H. Refleksi tentang Hukum, diterjemahkan Bernard Arief Sidharta, CitraAdityaBakti, Bandung, 1996.

Corstens, G.J.M, Het Nedelandse strafprocessrecht, Gouda-Quint, Arnhem, 1993.

Eddyono, Supriyadi Widodo \& Erasmus Napitupulu, "Prospek Hakim Pemeriksa Pendahuluan dalam Pengawasan Penahanan Dalam Rancangan KUHAP", Seri Pembaharuan Hukum Acara Pidana (policy paper 3/2014), Jakarta: Institute for Criminal Justice Reform, 2014.

Grenwood, Daniel J.H., "Beyond the Counter-Majoritarian Difficulty: Judicial Decision-Making in a Polynomic World", (Rutgers Law Review, Vol. 53, Summer 2001, No. 4): pp.781-862.

Graber, Mark A., "The Countermajoritarian Difficulty: From Courts to Congress to Constitutional Order", Annu. Rev.Law.Soc. Sci. 2008. 4:361-84.Groenhuijsen, M.S., Ilegally obtained evidence: An analysis of new trends in the criminal justice system of the Netherlands. In: The XIIIth World Congress of Procedural Law: The Belgian and Dutch Reports (pp.91-114), Unknown publisher, 2008.

Hadi, Ilman, "Miranda Rules" dalam Hukum Acara Pidana Indonesia, www.hukum.online.com, 13 Agustus 2012.

Hamzah, Andi, Hukum Acara Pidana Indonesia, Sinar Grafika, Jakarta, 2008. 
Hamzah, Andi, "Beberapa Hal dalam Rancangan KUHAP: Mengapa Perlu Menciptakan KUHAP Baru?," makalah diajukan pada pertemuan pembahasan RUU-KUHAP di Mataram, Mei 2013, www.aai.or.id (6/2/2015).

Hanifah, Lulu, "MK: Penetapan Tersangka Masuk Lingkup Praperadilan, 28 april 2015,www.mahkamahkonstitusi.go.id (6/2/2015).

Harahap, M. Yahya., Pembahasan Permasalahan dan Penerapan KUHAP Penyidikan dan Penuntutan, Sinar Grafika, Jakarta, 2006.

Pembahasan Permasalahan dan Penerapan KUHAP: Pemeriksaan Sidang Pengadilan, Banding, Kasasi dan Peninjauan Kembali, edisi kedua, Sinar Grafika, Jakarta, 2001.

Holmberg, Tom, "The Civil Code: An Overview - The Napoleon Series" dalam laman www.napoleon-series.org/research/government/code/c_code2. html (6/10/2015).

Ihsanuddin, “MK Putuskan Penetapan Tersangka Termasuk Obyek Praperadilan",Kompas.com, 28 april 2015.

Karjadi, M. \& R. Soesilo, Kitab Undang-undang Hukum Acara Pidana disertai dengan penjelasan resmi dan komentar, Politea, Bogor, 1988.

Loqman, Loebby, "Perkembangan Asas Legalitas dalam Hukum Pidana Indonesia", (makalah disampaikan pada Seminar tentang Asas-asas Hukum Pidana Nasional, diselenggarakan oleh BPHN dan Fakultas Hukum UNDIPSemarang, 26-27 april 2004).

Lubis, M. Sofyan, "Saksi Mahkota dalam Pembuktian Pidana" dalam laman www.kantorhukum-lhs.com (6/3/2015).

Mahendra, Yusril Ihza, "Yurisprudensi MA Menggeser KUHAP?"(www.ihzaihza.com; 6/3/2015).

Moeljatno, Kitab Undang-undang Hukum Acara Pidana, Bumi Aksara, Jakarta, 2003.

Platsas, Antonios Emmanuel, "The Functional and the Dysfunctional in the Comparative Method of Law: Some Critical Remarks, (Electronic Journal of Comparative Law, vol 12.3. (December 2008), http://www.ejcl.org; $(6 / 2 / 2015)$

Remmelink, Jan, Hukum Pidana: Komentar atas Pasal-pasal Terpenting dari KUHP Belanda dan Padanannya dalam KUHP Indonesia, Gramedia, Jakarta, 2003.

Rukmini, Mien, Perlindungan HAM melalui Asas Praduga Tidak Bersalah dan Asas Persamaan Kedudukan dalam Hukum pada Sistem Peradilan Pidana Indonesia, Alumni, Bandung, 2003.

Sabdo, Benny, "Kepastian Hukum yang Adil" 13 Mei 2015 dimuat dalam laman www.mahkamahkonstitusi.go.id (6/2/2015). 
Sapardjaja, Komariah Emong, Ajaran Sifat Melawan Hukum Materiil dalam Hukum Pidana Indonesia: Suatu Kasus tentang Penerapan dan Perkembanganya dalam Yurisprudensi, Alumni, Bandung, 2002.

Sidharta, "Asas Legalitas Apakah Hanya Berlaku di Ranah Hukum Material?" (15 maret 2015) www.business-lawbinus.ac.id (6/2/2015).

Sidharta, Bernard Arief, Ilmu Hukum Indonesia: Upaya Pengembangan Ilmu Hukum Sistematik yang Responsif terhadap Perubahan Masyarakat, Genta Publishing, Bandung, 2013.

Scholten, Paul, "De Structuur der Rechtswetenschappen", dalam G.J. Scholten, Y. Scholten, M.H. Bregstein, Verzamelde Geschriften van wijlen Prof.Mr. Paul Scholten, deel I, Zwolle: Tjeenk-Willink, 1949.

Yasin, Ikhsan Fatah, "Teori tentang Hierarki Peraturan Perundang-Undangan" (www.academia.edu. 6/9/2015).

Yasin, Muhammad, dalam jawabannya di www.hukumonline.com (Kekuatan Hukum Produk-produk Hukum MA (Perma, SEMA, Fatwa, SK KMA), 03 mei 2013, (6/10/2015).

www.putusan.mahkamahagung.go.id, (5-6/2/2015)

www.bawas.mahkamahagung.go.id, (5-6/2/2015)

www.mahkamahkonstitusi.go.id/index.php, (6/2/2015)

www.law.cornell.edu/wex (wex legal dictionary; 6/9/2015).

www.polri.go.id. , (5-6/2/2015)

UU 20/2001 (perubahan atas UU 31/1999) tentang Pemberantasan Tindak Pidana Korupsi

UU 46/ 2009 tentang Pengadilan Tindak Pidana Korupsi.

UU 26/ 2000 tentang Pengadilan Hak Asasi Manusia. 